\title{
Implementasi Kebijakan Badan Usaha Milik Desa Pandan Ningan di Desa Pendingan Kabupaten Musi Rawas
}

\section{The Implementation of the Pandan Ningan Village-Owned Business Agency in Pendingan Village Musi Rawas District}

\author{
Apsas Saputra, Budi Puspo Priyadi, Retno Sunu Astuti, \& Teuku Afrizal*.
}

Magister Administrasi Publik, Fakultas Ilmu Sosial dan Ilmu Politik, Universitas Diponegoro, Indonesia

Diterima: 26 Mei 2021 Direview: 26 Mei 2021; Disetujui: 08 Agustus 2021

*Coresponding Email: teukurian@lecturer.undip.ac.id

\begin{abstract}
Abstrak
Berdasarkan Peraturan Menteri Desa Nomor 4 Tahun 2015 tentang pendirian dan pengelolaan BUMDes bahwa setiap desa wajib memiliki badan usaha yang dikelola oleh pemerintah desa. Tulisan ini bertujuan untuk mengetahui implementasi kebijakan Badan Usaha Milik Desa Pandan Ningan dalam menyediakan gas elpiji di Desa Pendingan Kabupaten Musi Rawas. Masalah difokuskan pada masyarakat Desa Pendingan yang belum memiliki tabung gas secara pribadi. Penelitian ini menggunakan teori implementasi dari George C Edward III. Metode penelitian yang digunakan pada penelitian ini adalah metode deskriptif kualitatif. Sumber data diperoleh dari data primer dan data sekunder, teknik pengumpulan data melalui observasi, wawancara, dokumentasi. Hasil penelitian ini menunjukkan bahwa implementasi kebijakan badan usaha milik Desa Pandan Ningan dalam menyediakan gas elpiji di Desa Pendingan Kabupaten Musi Rawas dikatakan baik, hal tersebut karena Badan Usaha Milik Desa Pandan Ningan dapat memenuhi kebutuhan masyarakat. Selain itu, indikator dari teori Edward III sangat cocok digunakan dan dilaksanakan dalam penelitian. Dari empat indikator terdapat dua indikator yang dapat dikatakan optimal.

Kata Kunci: Implementasi kebijakan; Badan Usaha Milik Desa Pandan Ningan; Desa Pendingan; Kabupaten Musi Rawas.
\end{abstract}

\section{Abstract}

Based on the Village Ministerial Regulation Number 4 of 2015 concerning the establishment and management of BUMDes, each village is required to have a business entity managed by the village government. This paper aims to determine the implementation of the Pandan Ningan Village Owned Enterprise policy in providing LPG gas in Pendingan Village, Musi Rawas Regency. The problem is focused on the people of Pendingan Village who do not have gas cylinders personally. This research uses implementation theory from George C Edward III. The research method used in this research is descriptive qualitative method. Sources of data obtained from primary data and secondary data, data collection techniques through observation, interviews, documentation. The results of this study indicate that the implementation of the policy of the Pandan Ningan Village-owned business entity in providing LPG gas in Pendingan Village, Musi Rawas Regency is said to be good, this is because the Pandan Ningan Village-Owned Enterprise can meet the needs of the community. In addition, indicators from Edward III's theory are very suitable to be used and implemented in research. Of the four indicators, there are two indicators that can be said to be optimal.

Key words: Policy implementation; Pandan Ningan Village-owned enterprise; Pendingan Village; Musi Rawas Regency.

How to Cite: Saputra, A. Priyadi, B.P. Astuti, R.S. \& Afrizal, T. (2021). Implementasi Kebijakan Badan Usaha Milik Desa Pandan Ningan di Desa Pendingan Kabupaten Musi Rawas. Journal of Education, Humaniora and Social Sciences (JEHSS). 4(2): 782-792. 


\section{PENDAHULUAN}

Otonomi daerah ialah wewenang, dan hak yang dimiliki setiap daerah dalam mengatur dan mengurus segala pemerintahan dan kepentingan masyarakat sesuai dengan peraturan yang berlaku berlandaskan Pancasila. Berdasarkan Undang-Undang No 32 Tahun 2004tentang Pemerintahan Daerah bahwa undang-undang tersebut menjadi langkah awal dikeluarkannya peraturan mengenai otonomi daerah. Otonomi daerah membuat setiap daerah belajar mandiri dan menggalipotensi daerahnya masing-masing dan tidak bergantung dengan pemerintah pusat.

Perbaikan pola pikir dan pembangunan perlu dilakukan oleh pemerintah desa. Salah satu bentuk dari bukti kepedulian pemerintah akan potensi desa, yaitu melalui program dari Badan Usaha Milik Desa. Berdirinya BUMDes juga dilandasi oleh Undang-Undang Nomor 6 Tahun 2014 (Yasin et al., 2014)tentang desa dalam pasal 87 ayat 1 yang berbunyi, "desa dapat mendirikan Badan Usaha Milik Desa yang disebut BUMDes", dan ayat 2 yang berbunyi "BUMDes dikelola dengan semangat kekeluargaan dan kegotongroyongan," dan ayat 3 yang berbunyi "BUMDes dapat menjalankan usaha di bidang ekonomi dan atau pelayanan umum sesuai dengan ketentuanperundang-undangan". Sesuai dengan Peraturan Menteri Desa Pembangunan Daerah Tertinggal dan Transmigrasi Republik Indonesia, 2015:No 4tentang pendirian dan pengelolaan BUMDes, menjelaskan bahwa Badan Usaha Milik Desa atau dikenal dengan BUMDes sebagai bentuk wadah usaha yang seluruh permodalan berasal dari pemerintah desa dan didapatkan melalui kekayaan desa yang dipisahkan guna mengelola aset, jasa pelayanan, dan usaha lainnya untuk sebesar-besarnya kesejahteraan masyarakat desa.

BUMDes menjadi wadah yang dimiliki pemerintah untuk mengelola dan memanfaatkan potensi lokal suatu desa.BUMDes Pandan Ningan merupakan salah satu bentuk wadah bagi masyarakat guna mengelola potensi lokal dan menambah pendapatan asli desa.Badan Usaha Milik Desa (BUMDes) Pandan Ningan merupakan organisasi pemerintahan desa yang menaungi masyarakat dalam mengelola potensi desa.BUMDes Pandan Ningan yang terletak di Desa Pendingan Kecamatan Muara Lakitan Kabupaten Musi Rawas Provinsi Sumatera Selatan.Tahun 2017 menjadi langkah awal pemerintah Desa Pendingan untuk mengembangkan potensi desa melalui BUMDes.BUMDes Pandan Ningan yang dipimpin oleh Direktur memiliki kewajiban dan hak dalam mengatur dan menjakankan kegiatan BUMDes.Direktur BUMDes Pandan Ningan dalam menjalankan kegiatan dibantu tugasnya oleh anggota yang terdiri dari Sekretaris, Bendahara, Unit usaha, dan Pengawasan.

Berdasarkan Peraturan Desa Pendingan Nomor 10KPTSPND2017 Tentang Pembentukan Badan Usaha Milik Desa Pandan Ningan, n.dtentang pembentukan Badan Usaha Milik Desa Pandan Ningan, bahwa BUMDes Pandan Ningan dalam menjalankan kegiatannya dalam membantu memenuhi kebutuhan masyarakat dan menggali potensi lokal yang memiliki unit usaha bidang jasa, unit usaha bidang pertanian, peternakan dan perikanan serta unit usaha bidang dagang. Kebutuhan masyarakatyang semakin hari semakin meningkat membuat pemerintah desa meluncurkan unit usaha dagang terlebih dahulu. Kegiatan BUMDes Pandan Ningan tidak bisa berjalan secara beriringan, hal tersebut membuat BUMDes Pandan Ningan ini masih seumur jagung dalam mengelola kegiatan usaha dagang. Unit usaha dagang yang dijalankan oleh BUMDes Pandan Ningan ini, yaitu usaha dagang gas elpiji.

Berdirinya unit usaha dagang gas elpiji dari BUMDes Pandan Ningan berdasarkan keluhan dari masyarakat yang sulit mencari gas elpiji untuk menjadi bahan bakar memasak. Pemerintah desa dalam hal ini BUMDes Pandan Ningan melakukan gerakan guna memenuhi kebutuhan masyarakat mengingat gas elpiji menjadi kebutuhan pokok bagi masyarakat.Usaha dagang gas elpiji BUMDes Pandan Ningan diutamakan bagi seluruh kalangan masyarakat khususnya rumah tangga di Desa Pendingan. Pemerintah desa bekerja sama dengan para pengusaha yang ada di desa guna mencari dan memenuhi stok gas elpiji untuk disediakan pada BUMDes Pandan Ningan. Proses kegiatan dari usaha dagang gas elpiji yang dilakukan oleh BUMDes Pandan Ningan dapat dikatakan tidak berjalan dengan lancar. Hal tersebut disebabkan BUMDes Pandan Ningan memiliki stok gas elpiji yang terbatas dan mengalami kesulitan dalam mendapatkan gas elpiji untuk diberikan kepada masyarakat Desa Pendingan. 
Apsas Saputra, Budi Puspo Priyadi, Retno Sunu Astuti, \& Teuku Afrizal, Implementasi Kebijakan Badan Usaha

Milik Desa Pandan Ningan di Desa Pendingan Kabupaten Musi Rawas

Tabel. Jumlah masyarakat dan kepemilikan gas elpiji

\begin{tabular}{cccc}
\hline No & $\begin{array}{c}\text { Jumlah } \\
\text { gas }\end{array}$ & $\begin{array}{c}\text { Jumlah } \\
\text { penduduk }\end{array}$ & $\begin{array}{c}\text { Jumlah } \\
\text { pengguna } \\
\text { gas }\end{array}$ \\
\hline 1 & 200 & $\begin{array}{c}276 \text { Kartu } \\
\text { Keluarga } \\
\text { tabung }\end{array}$ & $\begin{array}{c}\text { 5o Kepala } \\
\text { Keluarga } \\
\end{array}$ \\
& jiwa \\
\end{tabular}

Sumber: Diolah Oleh Penulis Berdasarkan Badan Usaha Milik Desa Pandan Ningan

Berdasarkan Tabel 1 bahwa pelaksanaan pelayanan dari BUMDes Pandan Ningan mengenai usaha dagang gas elpiji memiliki 200 tabung gas elpiji. Tabung gas tersebut dipergunakan untuk mencari isi dari gas elpiji untuk memenuhi kebutuhan masyarakat Desa Pendingan. Akan tetapi Jumlah tabung gas yang dimiliki BUMDes Pandan Ningan masih tidak sebanding dengan jumlah penduduk Desa Pendingan.Desa Pendingan memiliki 1.082 Jiwa atau 276 Kepala Keluarga. Memenuhi kebutuhan masyarakat akan gas elpiji membuat BUMDes bekerja lebih keras dalam mencari gas elpiji. Hal tersebut terbukti dari masyarakat yang memiliki tabung gas sendiri hanya sebanyak 50 kepala keluarga.

Proses pelayanan yang dilakukan oleh BUMDes Pandan Ningan dalam menyediakan gas elpiji, yaitu melakukan kerjasama dengan Pertamina untuk menjadi pemasok gas elpiji di Desa Pendingan. Proses kerjasama yang dilakukan oleh BUMDes Pandan Ningan dengan Pertamina mengalami kesulitan, hal tersebut karena BUMDes Pandan Ningan yang kekurangan tabung gas elpiji dan tidak sesuai standar operasional pertamina yang harus memiliki 1200 tabung gas elpiji. Pertamina yang seharusnya menjadi pemasok gas elpiji bagi BUMDes melakukan penolakan untuk melakukan kerjasama. Pertamina menyarankan pihak BUMDes Pandan Ningan bekerja samadengan agen yang menjadi tangan kedua dari pertamina untuk pemasok gas elpiji. Agen yang menjadi pemasok gas elpiji bagi BUMDes Pandan Ningan memiliki jadwal tertentu untuk BUMDes dalam menyediakan gas elpiji.

Agen sebagai pemasok gas elpiji kepada BUMDes Pandan Ningan memberikan jadwal dua minggu sekali.BUMDes Pandan Ningan yang memiliki 200 tabung gas elpiji tidak bisa memiliki jadwal setiap minggu ataupun setiap saat untuk mendapatkan stok gas elpiji.BUMDes Pandan Ningan masih mengalami kesulitan dalam menyediakan gas elpiji bagi masyarakat Desa Pendingan. Lahirnya BUMDes Pandan Ningan bidang usaha dagang gas elpiji untuk memenuhi kebutuhan masyarakat, akan tetapi dalam pelaksanaan pelayanan BUMDes Pandan Ningan dalam menyediakan gas elpijibelum optimal dan masih membuat masyarakat kesulitan dalam mencari gas elpiji dan masih menggunakan kayu bakar sebagai bahan masak.

Tujuan pada penelitian ini, yaitu untuk mengetahui implementasi kebijakan badan usaha miliki Desa Pandan Ningan dalam menyediakan gas elpiji di Desa Pendingan Kabupaten Musi Rawas.Selain itu juga pada penelitian ini mengidentifikasi beberapa kendala dan upaya yang dilakukan dalam meningkatkan pendistribusian gas elpiji kepada masyarakat Desa Pendingan Kabupaten Musi Rawas.

Berkaitan dengan Badan Usaha Milik Desa, Berdasarkan buku panduan Departemen Pendidikan Nasional (2007:4) BUMDes adalah sebuah wadah bagi masyarakat desa yang berfungsi untuk memenuhi keinginan dan kebutuhan masyarakat melalui mencari dan mengelola potensi yang dimiliki oleh desa. Sesuai dengan Undang-undang nomor 4 tahun 2015 tentang pendirian, pengurusan dan pengelolaan, dan pembubaran Badan usaha milik desa(PDTT, 2015), menjelaskan bahwa BUMDes merupakan bentuk kepedulian pemerintah melalui kegiatan mengadakan pengelolaan usaha desa yang modal dari pengelolaan tersebut diambil dari keunggulan potensi 
desa dan kekayaan dimiliki desa dalam bentuk pengelolaan aset, jasa pelayanan, dan usaha lainnya.

Menurut Putra (2015:9)menjelaskan mengenai pengertian dari Badan Usaha Milik Desa, yaitu:

1. Badan Usaha Milik Desa atau BUMDes adalah bentuk dari strategi kebijakan dari pemerimtah melalui Kementerian Desa PDTTuntuk mensejahterakan masyarakat melalui tradisi desa.

2. Badan Usaha Milik Desa atau BUMDes adalah bentuk rancangan kepedulian dari pemerintah dalam membangun dan memajukan negara Indonesia melalui masyarakat pinggaran, hal tersebut dapat berupa mengembangkan potensi dari usaha ekonomi masyarakat desa yang bersifat kolektif.

3. Badan Usaha Milik Desa atau BUMDes adalah bentuk kepedulian pemerintah melalui kebijakan dalam mewujudkan kualitas hidup layak di masyarakat desa.

4. Badan Usaha Milik Desa atau BUMDes adalah wujud dari kemandirian dari perekonomian masyarakat desa melalui berbagai kegiatan-kegiatan usaha kreatif disusun oleh masyarakat desa.

Penelitian yang berkaitan dengan implementasi kebijakan badan usaha milik desa sangat banyak dilakukan. Akan tetapi, setiap penelitian yang dilakukan mengenai implementasi kebijakan badan usaha milik desa memiliki fokus dan hasil kajian yang berbeda-beda. Seperti halnya penelitian yang dilakukan oleh Puguh Budiono (2015) yang membahas mengenai Implementasi kebijakan badan usaha milik desa di Bojonegoro. Hasil penelitian yang dilakukan menunjukan bahwa hasil implementasi kebijakan badan usaha milik desa di Bojonegoro dipengaruhi oleh konteks atau lingkungan tempat yang dilakukan. Terdapat kepentingan individu dalam menjalankan kebijakan yang menjadi penghambat jalannya kebijakan. Hal tersebut karena adanya penguasaan potensi ekonomi individu dalam melaksanakan kebijakan sehingga tidak sesuai dengan tujuan dari kebijakan.

Penelitian lainnya mengenai implementasi kebijakan badan usaha milik desa dilakukan oleh Dine Meigawati (2015) mengenai implementasi program BUMDes di Kabupaten Suka Bumi. Hasil penelitian menunjukan bahwa hasil dari implementasi kebijakan tersebut dapat dikatakan baik, meskipun masih terdapat berbagai penghabat seperti halnya kekurangan sumber daya manusia, keadaan keuangan BUMDes yang kurang stabil, dan sosialisasi masih belum merta. Akan tetapi, dibalik itu semua terdapat partisipasi masyarakat yang relatif banyak sehingga kebijakan tersebut dapat berjalan. Selain itu, terdapat juga penelitian yang dilakukan oleh Salman Alfarizi dkk (2017) mengenai implementasi peraturan daerah tentang badan usaha milik desa (BUMDes). Hasil penelitian ini menyatakan bahwa hasil impelemtasi kebijakan badan usaha milik desa ini belum berjalan secara optimal. BUMDes tidak dapat memaksimalkan kekayaan yang dimiliki desa sehingga masih terdapat potensi desa yang terbengkalai dan keadaan perekonomian desa yang tidak stabil. Hal tersebut disebabkan karena kurangnya kemampuan dari aktor kebijakan dan partisipasi masyarakat yang rendah untuk ikut andil dalam kegiatan BUMDes.

Adapun teori yang di pakai peneliti dalam penulisan ini yaitu teori dari Goerge C. Edward III. Teori ini menjadi acuan bagi peneliti untuk mengetahui implementasi kebijakan badan usaha milik desa Pandan Ningan di Desa Pendingan Kabupaten Musi Rawas. Berdasarkan teori implementasi yang dijelaskan George C. Edward III bahwa terdapat empat variabel atau dimensi dalam model implementasi, yaitu komunikasi, sumberdaya, disposisi, dan struktur birokrasi. Model implementasi kebijakan dari George C, Edward III ini mampu menjawab dam menyelesaikan berbagai persoalan dalam implementasi Kebijakan Badan Usaha Miliki Desa Pandan Ningan Dalam Menyediakan Gas Elpiji Di Desa Pendingan Kabupaten Musi Rawas. Empat variabel menurut Edward III yang sangat menentukan keberhasilan implementasi suatu kebijakan, yaitu:

1. Komunikasi

Terdapat tiga indikator yang dapat dipakai dalam mengukur keberhasilan variabel komunikasi yaitu : Transmisi, Kejelasan dan Konsistensi 
Apsas Saputra, Budi Puspo Priyadi, Retno Sunu Astuti, \& Teuku Afrizal, Implementasi Kebijakan Badan Usaha

Milik Desa Pandan Ningan di Desa Pendingan Kabupaten Musi Rawas

2. Sumber Daya

Dimensi kedua dalam teori implementasi kebijakan dari Goerge C. Edward III yaitu sumber daya. Terdapat 4 Indikator yang digunakan melihat keberhasilan dari dimensi sumber daya, yaitu: Staf, Informasi, Wewenang, dan Fasilitas.

3. Disposisi

Disposisi adalah watak dan karakteristik yang dimiliki oleh implementor, seperti komitmen, kejujuran dan sifat demokratis. Terdapat 2 indikator penting dalam dimensi atau variabel disposisi yaitu Pengangkatan Birokrat dan Insentif.

4. Struktur birokrasi

Dua karakteristik, menurut Edward III, yang dapat mendongkrak kinerja struktur birokrasi/organisasi kearah yang lebih baik, yaitu dengan melakukan Standar Operating Prosedures (SOP) dan Fragmentasi.

\section{METODE PENELITIAN}

Penelitian ini menggunakan metode deskriptif kualitatif yang bertujuan untuk mendeskripsikan segala bentuk gejala sosial. Menurut Sugiyono (2005) penelitian deskriptif kualitatif adalah suatu metode yang digunakan untuk menggambarkan atau menganalisis suatu hasil penelitian tetapi tidak digunakan untuk membuat kesimpulan lebih luas. Penelitian kualitatif dalam penelitian ini memberikan informasi secara lengkapbermanfaat bagi perkembangan ilmu pengetahuan serta dapat diterapkan pada berbagai masalah mengenai implementasi kebijakan Badan Usaha Miliki Desa Pandan Ningan dalam menyediakan gas elpiji di Desa Pendingan Kabupaten Musi Rawas. Lokasi penelitian yang dipilih di Desa Pendingan Kabupaten Musi Rawas.

Informan penelitian dipilih bedasarkan purposive sampling yang ditentukan secara langsung berdasarka kriteria tertentu Creswell (2013). Informan penelitian berupa Kepala Desa Pendingan Kabupaten Musi Rawas, Direktur Badan Usaha Milik Desa Pandan Ningan, Bendahara Badan Usaha Milik Desa Pandan Ningan, Kepala Unit Usaha Badan Usaha Milik Desa Pandan Ningan, dan masyarakat Desa Pendingan Kabupaten Musi Rawas. Tenik pengumpulan data pada penulisan ini terdiri dari observasi, wawancara dan dokumentasi. Observasi pada penulisan ini dilakukan secara langsung pada objek yang di teliti. Dalam hal ini peneliti melakukan pengamatan di Desa Pendingan Kabupaten Musi Rawas. Setelah melaksanakan observasi, peneliti melakukan tahapan wawancara terhadap informan. Proses wawancara dilakukan kepada pegawai badan usaha milik desa dengan cara memberikan berbagai pertanyaan yang berkaitan penulisan. Pertanyaan yang diberikan kepada pengawai disusun dalam bentuk pedoman wawancara. Tahap akhir dari pengumpulan data yaitu dokumentasi. Menurut Usman (2008) dokumentasi berupa teknik mengklasifikasi yang nantinya harus mempelajari dokumen yang berkaitan dengan penelitian. Dokumentasi berupa pengambilan gambar dan pengambilan berkas berupa laporan secara langsung oleh peneliti baik dalam kegiatan observasi maupun wawancara.

\section{HASIL DAN PEMBAHASAN}

Proses analisis yang dilakukan berdasarkan data-data yang diperoleh mengenai implementasi kebijakan Badan Usaha Miliki Desa Pandan Ningan di Desa Pendingan Kabupaten Musi Rawas sesuai dengan teori implementasi dari George C. Edward III. Berdasarkan teori tersebut memiliki empat dimensi yang berupa komunikasi, sumber daya, disposisi, dan struktur organisasi. Adapun penjelasan analisis dan interpretasi data yang di peroleh sesuai dengan empat dimensi teori implementasi tersebut, yaitu:

A. Komunikasi

Komunikasi adalah indikator atau dimensi awal dari model implementasi George C Edward III yang sangat berpengaruh terhadap keberhasilan kebijakan. Suatu implementasi dapat dikatakan efektif ketika aktor pembuat keputusan dari suatu kebijakan memahami secara detail tentang kebijakan yang dibuat. Komunikasidalam suatu kebijakan sangatlah penting, tanpa adanya komunikasi kebijakan tersebut mengalami hambatan atau tidak berjalan dengan sempurna.

Kebijakan Badan Usaha Milik Desa Pandan Ningan dalam menyediakan gas elpiji bagi masyarakat Desa Pendingan memerlukan komunikasi yang akurat dan searah dengan tujuan. Hal 
tersebut agar nantinya pelaksanaan dari kebijakan yang dijalankan dapat berjalan lancar. Berdasarkan teori implementasi dari George C Edward III bahwa dimensi dari komunikasi terdapat tiga indikator yang mempengaruhi keberhasilan kebijakan dari Badan Usaha Milik Desa Pandan Ningan, yaitu:

\section{Transmisi}

Transmisi merupakan sebuah indikator dari komunikasi berdasarkan teori implementasi dari George C Edward III. Transmisi berbentuk penyampaian sebuah informasi ataupun komunikasi dalam sebuah kebijakan. Transmisi yang dilakukan dalam kebijakan Badan Usaha Milik Desa Pandan Ningan dapat berupa penyampaian informasi dari pihak BUMDes kepada masyarakat mengenai pendistribusian gas elpiji. Penyampaian informasi tersebut disampaikan langsung oleh direktur BUMDes Pandan Ningan melalui pengumuman desa yang disampaikan di kantor kepala desa. Penyampaian informasi tersebut dilakukan setiap kali gas elpiji masuk kedalam desa melalui BUMDes Pandan Ningan.

Selain itu, BUMDes Pandan Ningan juga melakukan transmisi kepada pihak pemerintah desa dalam hal ini kepala desa Pendingan. Penyampaian komunikasi tersebut dilakukan secara langsung ketika kepala desa melakukan pemantauan kegiatan distribusi gas elpiji sedang berlangsung. Selaku pimpinan desa, kepala desa terus melakukan sebuah terobosan yang berfungsi untuk mensejahterahkan masyarakat. Kepala desa melakukan pengawasan dan pemantauan terhadap kegiatan yang dijalankan oleh BUMDes Pandan Ningan.

Kejelasan

Kejelasan merupakan bentuk informasi yang diperoleh oleh aktor kebijakan harus jelas dan tidak diperbolehkan mendapatkan informasi dua arah atau bertolak belakang. Pada pelaksanaan kegiatan BUMDes dalam menyediakan gas elpiji kepada masyarakat memiliki informasi cukup jelas. Hal tersebut dilihat dari jadwal pendistribusian gas elpiji kepada masyarakat sesuai dengan jadwal yang berlaku yakni dua minggu sekali. Kejelasan informasi yang diterima oleh masyarakat akan gas elpiji membuat respon positif dari masayarakat terhadap BUMDes Pandan Ningan.

Masyarakat tidak memerlukan waktu yang cukup lama untuk menunggu kedantangan gas elpiji yang disediakan oleh BUMDes Pandan Ningan. Gas elpiji yang menjadi bahan pokok bagi masyarakat mengharuskan bagi BUMDes Pandan Ningan untuk terus menyediakan stok gas elpiji untuk diberikan kepada masayarakat. Gas elpiji yang diterima oleh BUMDes Pandan Ningan berasal agen pertamina. Agen tersebut merupakan tangan kanan dari pertamina untuk mendistribusikan gas elpiji. BUMDes Pandan Ningan hanya mendapatkan 200 tabung gas elpiji setiap sekali masuk. Agen memiliki informasi jelas kepada BUMDes yaitu gas elpiji masuk ke BUMDes Pandan Ningan satu bulan dua kali. Informasi yang diterima oleh BUMDes disampaikan kepada pemerintah desa dan masyarakat sesuai dengan informasi yang disampaikan oleh agen.

Konsistensi

Konsistensi merupakan ketetapan dalam komunikasi yang berupa informasi yang diterima ataupun disampaikan harus memiliki konsisten, agar informasi dapat berupa perintah dapat jelas dan sesuai dengan arahan yang diberikan. Sering terjadi kesalahan dalam pelaksanaan suatu kebijakan, hal tersebut dikarenakan terdapat informasi atau perintah yang tidak sesuai dengan pedoman ataupun aturan yang ada. BUMDes Pandan Ningan memiliki aturan yang menjadi pedoman yaitu Peraturan Desa Pendingan Nomor 10/KPTS/PND/2017 mengenai pembentukan badan usaha milik desa pandan ningan.

Informasi yang diterima oleh BUMDes dari agen ataupun kepala desa dapat diterima dan disampaikan secara baik dan jelas, sehingga informasi tersebut konsisten dan tidak mudah dapat diberubah sewaktu-waktu. Berpegang pada aturan dari pemerintah desa bahwa BUMDes Pandan Ningan bertindak dan mengelola kegiatan dari BUMDes Pandan Ningan sesuai dengan aturan tersebut. 


\section{B. Sumber Daya}

Dimensi kedua dari teori Implementasi dari George C Edward III yaitu sumber daya. Sumber daya adalah sebuah potensi yang dimiliki dalam suatu kebijakan dalam hal ini sumber daya menjadi faktor penting dikarenakan sumber daya sebagai aktor penggerak suatu kebijakan. Berdasarkan teori implementasi Edward III terdapat empat indikator dalam dimensi sumber daya guna mengukur tingkat dari suatu keberhasilan pelaksanaan kebijakan BUMDes Pandan Ningan, yaitu:

\section{a. Staff}

Kekuatan dari sumber daya pada teori implementasi ini yaitu staff ataupun pegawai. Pegawai sebagai aktor dalam pelaksanaan kebijakan. Sering terjadi kegagalan pada pelaksanaan kebijakan akibat dari keadaan dan kondisi staff yang belum memadai dan tidak memahami bidang kerja yang dilakukan. Implementasi kebijakan dari BUMDes Pandan Ningan dapat dikatakan belum optimal, dikarenakan BUMDes hanya memiliki lima staff atau pegawai yang menyebabkan sering terjadi kegiatan dari BUMDes mengalami terbengkalai. Pelaksanaan dan pengelolaan gas elpiji dari BUMDes Pandan Ningan tidak cukup dengan lima staf yang dimiliki.

Berdasarkan hasil observasi sering dijumpai kekosongan staff dalam BUMDes Pandan Ningan, hal tersebut disebabkan karena staff dari BUMDes selalu terlambat datang ke tempat pelaksanaan distribusi gas elpiji. Staff BUMDes hanya tepat waktu datang ketika gas elpiji masuk desa melalui distribusi oleh agen. Pada kegiatan distribusi gas elpiji tersebut membuat seluruh staff hadir dan ikut andil dikarenakan pada kegiatan ini langsung di kontrol dan disaksikan oleh kepala desa pendingan.

b. Informasi

Menurut Winarno (2007:183-184) terdapat dua jenis informasi dari implementasi kebijakan, yaitu:

1. Informasi yang berkaitan erat terhadap tata cara pelaksanaan suatu kebiajakan.

2. informasi yang berkaitan tentang data kepatuhan oleh aktor kebijakan kepada aturan yang dikeluarkan dan ditetapkan oleh pemerintah secara sah.

Informasi mengenai pendistribusian gas elpiji yang dilakukan oleh BUMDes Pandan Ningan kepada masyarakat dilihat dan disampaikan melalui pengumuman di kantor kepala desa. Setiap dua minggu sekali pihak BUMDes menyampaikan informasi mengenai distribusi gas elpiji kepada masyarakat. Ketika telah mendapatkan pengumuman biasanya masyarakat langsung bergegas untuk melakukan pembelian gas elpiji kepada pihak BUMDes.

Tidak seluruh masyarakat desa pendingan memiliki tabung gas elpiji, melainkan pihak BUMDes meminjamkan tabung gas tersebut kepada masyarakat. Proses peminjaman tabung gas elpiji yang dilakukan oleh masyarakat khusus yang tidak memiliki tabung gas saja. Masyarakat hanya dapat menunjukan fotocopy kartu keluarga yang dimiliki dan diberikan kepada pihak BUMDes, maka setelah itu pihak BUMDes meminjamkan tabung gas kepada masyarakat yang tidak memiliki tabung gas.

\section{c. Wewenang}

Wewenang merupakan suatu hak ataupun kekuasaan yang dimiliki oleh badan atau instansi untuk melakukan sesuatu guna mencapai tujuan yang telah ditentukan sebelumnya. Wewenang biasanya ditujukan kepada orang lain sesuai dengan tugas, pokok dan fungsi masingmasing unit. Berdasarkan hasil observasi dan penelitian bahwa kewenangan yang terjadi pada kegiatan BUMDes Pandan Ningan yaitu pihak BUMDes meminjamkan tabung gas elpiji kepada masyarakat. Jumlah masyarakat yang ada di Desa Pendingan tidak sebanding dengan jumlah masyarakat yang memiliki tabung gas secara pribadi. Masyarakat yang memiliki tabung gas secara prbadi hanya terdapat 50 kartu keluarga, sedangkan jumlah masyarakat per kepala keluarga yaitu berjumlah 276 kartu keluarga. hal tersebut menyebabkan kekurangan stok gas elpiji yang akan ditukarkan kepada masyarakat.

BUMDes Pandan Ningan mengeluarkan wewenang yang bersifat membantu masyarakat untuk menggunakan gas elpiji. Masyarakat dapat meminjamkan tabung gas dari BUMDes dengan cara menunjukan fotocopy kartu keluarga kepada pihak BUMDes. Selain syarat fotocopy kartu keluarga pihak BUMDes memiliki kesepakatan dengan masyarakat yang meminjamkan tabung 
gas. Kesepakatan tersebut yaitu masyarakat harus mengembalikan tabung gas yang dipinjam sampai dengan kedatangan dan distribusi kembali oleh pihak agen.

\section{d. Fasilitas}

Fasilitas merupakan sebuah indikator penting dalam pelaksanaan suatu kebijakan. Fasilitas sebagai penunjang kegiatan dari kebijakan yang dapat berupa sarana dan prasarana. Kebijakan dapat dikatakan berhasil apabila memiliki fasilitas yang memadai untuk menunjang kinerja dari aktor kebijakan. Kebijakan BUMDes Pandan Ningan dalam menyediakan gas elpiji kepada masyarakat harus memiliki fasilitas yang memadai dalam membantu proses pengelolaan dan pelaksanaan kebijakan tersebut. Adapun fasilitas yang dimiliki oleh BUMDes Pandan Ningan sebagai berikut, yaitu:

Tabel 2. Jumlah Fasilitas di BUMDes Pandan Ningan

\begin{tabular}{cccc}
\hline No & Jenis Fasilitas & $\begin{array}{c}\text { Jumlah } \\
\text { (Unit) }\end{array}$ & Keterangan \\
\hline 1. & Gedung & 1 unit & Baik (sewa) \\
\hline 2. & Gas Elpiji & 200 unit & Baik \\
\hline 3. & Komputer & Baik & 1 \\
\hline 4. & Laptop & Baik & $\mathbf{2}$ \\
\hline 5 & Printer & Baik & $\mathbf{1}$ \\
\hline 6. & Meja Kerja & Baik & $\mathbf{2}$ \\
\hline 7. & Kursi & Baik & 4 \\
\hline 8. & Motor gas elpiji & $\begin{array}{c}\text { Kurang } \\
\text { Baik }\end{array}$ & $\mathbf{1}$ \\
\hline 9 & $\begin{array}{c}\text { Kertas, Pena dan } \\
\text { sebagainya }\end{array}$ & Baik & Mencukupi
\end{tabular}

Sumber: Diolah oleh Penulis dari Badan Usaha Milik Desa Pandan Ningan

Berdasarkan tabel 2 dinyatakan bahwa fasilitas yang dimiliki oleh BUMDes Pandan Ningan belum memadai. Masih terdapat fasilitas yang bersifat non pribadi atau sewa seperti halnya gedung yang menjadi pusat kegiatan dari BUMDes Pandan Ningan. Pihak BUMDes menyewa ruko ataupun gedung miliki masyarakat untuk dijadikan tempat kegiatan distribusi gas elpiji. Setiap tahun pihak BUMDes mengeluarkan anggaran gedung sebesar Rp. 3.600 .000 per tahun. Anggaran yang dikeluarkan untuk membayar sewa gedung dapat dikatakan tidak optimal terhadap anggaran yang lebih bersifat pada boros anggaran.

Selain itu fasilitas yang dimiliki BUMDes pandan ningan kurang layak, dikarenakan kondisi dan kualitas barang yang dimiliki tidak menunjang dari pelaksanaan dan pengelolaan kegiatan BUMDes. Salah satu fasilitas yang kurang layak yaitu sepeda motor sebagai pengangkut gas elpiji. Berdasarkan hasil penelitian dan observasi bahwa fasilitas sepeda motor tersebut sering terjadi kerusakan dan menyebabkan pendistribusian gas elpiji kepada masyarakat menjadi terhambat. Hal tersebut dikarenakan pihak BUMDes membeli motor dengan kondisi kurang layak dan bersifat barang bekas.

\section{Disposisi}

Disposisi merupakan karakteristik yang dimiliki oleh aktor kebijakan yang bersifat mutlak seperti halnya kejujuran dan komitmen. Keberhasilan suatu kebijakan dapat dilihat dari cara dari aktor kebijakan dalam melakukan implementasi kebijakan. Ketika aktor kebijakan menjalankan sesuai aturan dan bersikap positif, maka implementasi kebijakan akan berjalan sesuai rencana yang disusun. Akan tetapi ketika aktor kebijakan menjalankan tidak sesuai aturan ataupun bersikap negatif, maka implementasi kebijakan akan mengalami hambatan dan masalah. Berdasarkan teori implementasi dari George C Edward III bahwa disposisi memiliki dua indikator penunjang keberhasilan dalam implementasi kebijakan, yaitu :

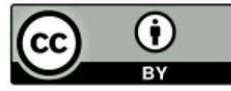


Apsas Saputra, Budi Puspo Priyadi, Retno Sunu Astuti, \& Teuku Afrizal, Implementasi Kebijakan Badan Usaha

Milik Desa Pandan Ningan di Desa Pendingan Kabupaten Musi Rawas

\section{a. Pengangkatan Birokrat}

Pengangkatan birokrat merupakan suatu kebijakan yang diambil oleh aktor kebijakan untuk membantu jalannya pelaksanaan dan pengelolaan tersebut. Pada kebijakan BUMDes Pandan Ningan, pengangkatan birokrat sangat penting untuk menunjang kegiatan pendistribusian gas elpiji kepada masyarakat. Pengangkatan birokrat biasanya dilakukan dengan cara penunjukan kepada staff terhadap posisi atau bidang yang sesuai dengan keahlian dan kemampuan dari staff tersebut. BUMDes Pandan Ningan terdiri dari direktur utama, sekretaris, bendahara, kepala bidang unit usaha, dan unit usaha bidang gas elpiji. Selaku pimpinan tertinggi BUMDes pandan ningan seorang direktur memberikan tugas pokok dan fungsi dari setiap bagian. Pengangkatan birokrat di BUMDes Pandan Ningan berupa penunjukan tugas kepada staff dalam hal ini unit usaha gas elpiji untuk mencari agen yang dijadikan sebagai penyuplai gas elpiji kepada BUMDes Pandan Ningan.

b. Insentif

Insentif merupakan sebuah imbalan yang diberikan kepada pegawai atau aktor kebijakan yang berfungsi untuk apresiasi dari kinerja dalam implementasi suatu kebijakan. Insentif juga bertujuan untuk menambah semangat kinerja dari aktor kebijakan. Pada pelaksanaan BUMDes Pandan Ningan tidak terdapat insentif tambaham dari pemerintah desa. Setiap staff dari BUMDes memiliki penghasilan yang sesuai dengan ketetapan kepala desa. Anggaran tersebut bersumber dari Anggaran Pendapatan Belanja Negara (APBN). Meskipun tidak mendapatkan insentif dari pemerintah desa, staff BUMDes sering kali mendapatkan sebuah insentif yang berasal dari masyarakat tanpa ada paksaan dalam hal ini yaitu ucapan terima kasih oleh masyarakat kepada staff tersebut telah mengantarkan gas elpiji kerumah masyarakat tersebut.

\section{Struktur Birokrasi}

Dimensi keempat dalam model implementasi menurut George C Edward III yaitu struktur birokrasi. Tatanan strukrut birokrasi menuntut seluruh pihak ikut terlibat dalam implementasi kebijakan. Sehingga ketika struktur birokrasi tidak berfungsi maka tatanan sumber daya pada kebijakan tersebut mengalami stagnan dan tidak dapat berjalan sesuai tujuan dan aturan yang berlaku. Pelayanan publik dari suatu instansi dapat dikatakan berhasil ketika memiliki birokrasi yang jelas dan mendukung jalanya kebijakan yang dibuat. Berdasarkan teori implementasi Edward III terdapat dua bentuk dari struktur birokrasi, yaitu:

\section{a. Standar Operating Prosedures (SOP)}

Standar Operating Prosedures atau dikenal dengan SOP merupakan sebuah alur atau pedoman yang dimiliki oleh suatu instansi dalam menjalankan kebijakan. Seluruh orang yang terlibat dalam kebijakan patuh terhadap SOP yang berlaku. Berpegang teguh pada aturan dan SOP yang ada membuat para aktor kebijakan memiliki standar minimum yang diperoleh dari kebijakan tersebut.

Berdasarkan hasil penelitian dan observasi bahwa pelaksanaan dan pengelolaa dari kebijakan BUMDes Pandan Ningan untuk menyediakan gas elpiji kepada masyarakat belum memiliki Standar Operasional Prosedur atau SOP. Dalam pelaksanaan dan pengelolaan gas elpiji oleh BUMDes hanya berpegang teguh pada Peraturan Desa Pendingan Nomor 10/ KPTS/ PND/ 2017mengenai pembentukan badan usaha milik desa pandan ningan. Selain itu, pihak BUMDes juga melakukan distribusi gas elpiji kepada masyarakat diawali dengan pengumuman secara langsung melalui kantor desa. Sehingga melalui informasi tersebut membuat masyarakat sudah mengetahui secara otomati bahwa distribusi gas elpiji akan berlangsung pada hari itu.

\section{b. Fragmentasi}

Fragmentasi merupakan bentuk dari sebuah koordinasi yang berupa pembagian tanggung jawab dan wewenang kepada seluruh staff dari instansi. Pada tahap fragmentasi ini untuk memperlihatkan cara koordinasi yang dilakukan oleh setiap staff. Kebijakan BUMDes Pandan Ningan yang menyediakan gas elpiji dilakukan oleh aktor kebijakan yang beranggotakan lima orang. Seluruh anggota staff dari BUMDes Pandan Ningan memiliki tugas dan wewenang masing-masing serta melakukan koordinasi keapda setiap bagian. Koordinasi yang dilakukan oleh staff BUMDes Pandan Ningan lebih mementingkan kerjasama antar anggota staff. 
Salah satu bentuk koordinasi yang dilakukan oleh BUMDes Pandan Ningan yaitu melakukan koordinasi pendistribusian gas elpiji. Kegiatan pendistribusian gas elpiji diawali oleh unit usaha gas elpiji yang melakukan pencarian agen untuk menjadi penyuplai gas elpiji, kemudian jalannya koordinasi berjalan dengan lancar kepada unit usaha untuk menyusun jadwal pendistribusian gas elpiji kepada masyarakat. Seluruh koordinasi yang dilakukan oleh staff BUMDes di lakukan pengawasan langsung oleh kepala desa dan direktur utama BUMDes pandan ningan.

\section{SIMPULAN}

Berdasarkan hasil penelitian dan observasi mengenai implementasi kebijakan badan usaha milik desa pandan ningan di Desa Pendingan Kabupaten Musi Rawas bahwa dapat dinyatakan implementasi kebijakan tersebut berjalan dengan baik. Sesuai dengan teori dari George C Edward III, berikut dapat disimpulkan dari hasil penelitian dan observasi dengan empat dimensi dari Edward III, yaitu:

1. Komunikasi, pada dimensi komunikasi terdapat tiga indikator yaitu transmisi, kejelasan, dan konsistensi. Pada dimensi dan indikator ini dapat dikatakan berjalan dengan baik sesuai dengan aturan. Meskipun terdapat penyampaian informasi atau transmisi secara tradisional melalui kantor kepala desa.

2. Sumber daya, pada dimensi sumber daya terdapat empat indikator yaitu staff, informasi, wewenang dan fasilitas. Pada indikator dan dimensi ini dapat dikatakan belum optimal, dikarenakan pada indikator staff mengalami kekurangan staff dari pihak BUMDes Pandan Ningan. Selain itu pada indikator fasilitas masih terdapat beberapa fasilitas yang tidak memadai dan tidak layak untuk digunakan untuk menunjang implementasi kebijakan.

3. Disposisi, pada dimensi disposisi memiliki dua indikator penunjang kegiatan dari BUMDes Pandan Ningan yaitu pengangkatan birokrat dan insentif. Pada indikator ini dapat dikatakan baik, meskipun dari pihak BUMDes tidak menyediakan insentif bagi staff. Akan tetapi hal tersebut tidak mengurangi kinerja dari staff BUMDes Pandan Ningan.

4. Struktur birokrasi, pada dimensi ini memiliki dua indikator yang membantu dalam implementasi kebijakan yaitu Standar Operasional Prosedur dan Fragmentasi. Pada indikator ini belum dapat dikatakan baik dikarenakan BUMDes Pandan Ningan belum memiliki Standar Operasional Prosedur untuk menjadi pedoman dalam kebijakan.

\section{DAFTAR PUSTAKA}

Alfarizi, Salman dkk. (2017). Implementasi Peraturan Daerah Tentang Badan Usaha Milik Desa BUMDes. Jurnal Ilmu Administrasi Negara, Volume 14, Nomor 3, Juli 2017 : 279-287

Budiono, Puguh. (2015). Implementasi Kebijakan Badan Usaha Milik Desa (BUMDes) di Bojonegoro (Studi di Desa Ngringinrejo Kecamatan Kalitidu dan Desa Kedungprimpen Kecamatan Kanor).

Bumulo, R. M., Lambey, L., \&Mawikere, L. M. (2018). Analisis Efektivitas Penggunaan Anggaran Sebagai Alat Pengendalian Belanja Langsung Pada Biro HukumProvinsi Sulawesi Utara.Going Concern: Jurnal Riset Akuntansi, 14 (1), 363-371. https://doi.org/10.32400/gc.13.04.21159.2018

Creswell, John W. (2013). Research Design (Pendekatan Kualitatif, Kuantitatif dan Mixed). Yogyakarta: Pustaka Pelajar.

Departemen Pendidikan Nasional. 2007. Pendirian dan Pengelolaan Badan Usaha Milik Desa. Pusat Kajian Dinamika Sistem Pembangunan (PKDSP). Fakultas Ekonomi. Universitas Brawijaya.

Kadek, N., Candra, D., Sinarwati, N. K., \&Arie, M. (2017). Efektivitas pengelolaan dana pada Badan Usaha Milik Desa Kerta dan Umandara di Desa Songan a. E-Journal S1 Ak Universitas Pendidikan Ganesha, 8 (2), $1-10$.

PDTT, P. (2015). Pendirian, Pengurusan, dan Pengelolaan, dan Pembubaran Badan Usaha Milik Desa.

Peraturan Desa Pendingan Nomor 10KPTSPND2017 Tentang Pembentukan Badan Usaha Milik Desa Pandan Ningan. (n.d.).

Peraturan Menteri Desa Pembangunan Daerah Tertinggal dan Transmigrasi Republik Indonesia. (2015). Pendirian, pengurusan dan pengelolaan, dan pembubaran badan usaha milik desa. 1-11.

Putra, A. S. (2015). Buku \& Badan Usaha Milik Desa, Spirit Usaha Kolektif Desa. Kementerian Desa, Pembangunan Daerah Tertinggal dan Transmigrasi Republik Indonesia. 
Apsas Saputra, Budi Puspo Priyadi, Retno Sunu Astuti, \& Teuku Afrizal, Implementasi Kebijakan Badan Usaha Milik Desa Pandan Ningan di Desa Pendingan Kabupaten Musi Rawas

Meigawati, Dine. Implementasi Program BUMDes di Kabupaten Sukabumi (Studi Kasus Desa Cisande Kecamatan Cicantayan. Proceeding - Konferensi Nasional Ilmu Administrasi 2.0.

Negara, J. I. A. (2018). Pengelolaan Dana Badan Usaha Milik Desa (Bumdes) Putak Jaya Di Desa Putak Kecamatan Gelumbang Kabupaten $\quad$ Muara Https://Repository.Unsri.Ac.Id/12249/1/Rama 6320107011181419200002412600301 Front Ref.Pdf

Sugiyono. (2005). Metode Penelitian Kuantitatif, Kualitatif, dan R\&D. Alfabeta.

Undang-Undang No 32 Tahun 2004, T. P. D. (2004). Undang-Undang No 32 Tahun 2004 Tentang Pemerintah Daerah. Dpr, 249. http://www.dpr.go.id/dokjdih/document/uu/33.pdf

Usman, H., dan Akbar, P.S. (2008). Metode Penelitian Sosial. Jakarta. Bumi Aksara.

Wati, Rina dkk. (2020). Implementasi Kebijakan Badan Usaha Milik Desa (BUMDes) di Kecamatan Pondidaha Kabupaten Konawe. Publica: Jurnal Administrasi Pembangunan dan Kebijakan Publik Vol. 11 No. 1 Februari 2020

Yasin, M., K, A. R., Fachurrahman, Untung, B., Rostanty, M., Dwiherwanto, S., Saharudin, I., \& Muslih, F. (2014). Undang-Undang No . 6 Ta Hun 2014. Pusat Telaah Dan Informasi Regional (PATTIRO), 6. 